\title{
Effect of feeding level on milk production of sows during four weeks of lactation
}

\author{
G. J. M. van Kempen ${ }^{1 *}$, C. Geerse ${ }^{1 *}$, M. W. A. Verstegen ${ }^{1,2}$ and J. Mesu ${ }^{1}$ \\ ${ }^{1}$ Department of Animal Nutrition, Agricultural University, Haagsteeg 4, 6708 PM \\ Wageningen, Netherlands \\ ${ }^{2}$ Department of Animal Husbandry, Agricultural University, Marijkeweg 40, 6709 \\ PG Wageningen, Netherlands
}

Received 14 August 1984; accepted 1 February 1985

Key-words: sow, feeding level, milk production, milk composition

\section{Summary}

Twelve Crossbred sows (second parity Dutch landrace $\times$ Norvegian landrace) were used in a balance study. Two feeding levels (with $12.5 \mathrm{MJ}$ metabolizable energy (ME) per kg) were applied. The low level was about $2.5 \mathrm{~kg} / \mathrm{d}\left(0.8 \mathrm{MJ} \mathrm{ME} / \mathrm{kg}^{3 / 4}\right)$ and supplied ample energy for maintenance. Milk needed to be produced from body reserves. The high feeding level was about $5.3 \mathrm{~kg}\left(1.5 \mathrm{MJ} \mathrm{ME} / \mathrm{kg}^{3 / 4}\right)$ and supplied sufficient energy for maintenance and, in addition to that, some energy for milk production. Milk production was determined at day 5, 10, 15, 20 and 25 of lactation. Milk production peaked at about 15 days at the low level and at about 20 days at the high level. A high feeding level increased milk production after 10 days. Composition of milk was significantly affected by feeding level. Dry matter, fat and protein contents in milk were reduced somewhat in the high level sows. However, piglets ingested still more milk components from sows at the high level and gained more weight. Also, feed conversion ratio of milk per unit of gain was more favourable (lower) in piglets from sows receiving the high feeding level. Energy and $\mathrm{N}$ balance were measured with each sow in week 2 and week 4 of lactation. Digestibility of feed was decreased at the high feeding level. However, measured metabolizable energy content of the feed was similar and was not affected by stage of lactation. Sows receiving the low level of feed lost 13 and $8.5 \mathrm{~kg}$ of bodyweight respectively in these two weeks. At the high level they lost 3.3 and $1.3 \mathrm{~kg}$ respectively. It is concluded that a high feeding level is beneficial in two ways: to prevent high weight losses in sows and for a better development in suckling pigs.

\footnotetext{
* Trouw \& Co. B.V. International, Research and Development, Nijverheidsweg 2, 3881 LA Putten, Netherlands.
} 


\section{Introduction}

Nutritional requirements of sows during lactation are not very well known. Most studies have been performed with the assumption that change in body weight of the sows can be used as an estimate for changes in energy content of the body (Bowland, 1967; Aherne \& Speer, 1974). De Lange et al. (1980) have estimated that milk in sows was produced with an efficiency of 48 to $70 \%$ from metabolizable energy in feed or from energy stored in the body. Compared with cows, however, estimates from sows are more difficult to make due to errors associated with milk production determination and with obtaining a correct sample (den Hartog et al., 1984).

The evaluation of nutritional requirements of sows for lactation based on these efficiencies depend on accuracy with which milk production and efficiency can be estimated from energy balance data. Klaver et al. (1981) investigated milk production in lactating sows during a 10-day lactation period. This experimental period may be too short to measure milk production accurately.

Since weight changes in piglets are used as parameter for milk production, the best estimation of quantity of milk and of efficiency of milk production can be made at the time of maximum milk production, i.e. day 25 of lactation (den Hartog et al., 1984).

The present experiments were performed to measure digestibility of feed in lactating sows and to study the effect of feeding level on milk production during four weeks post partum; sows were, in contrast to the experiment of Klaver et al. (1981), all in a good condition.

\section{Materials and methods}

Sows. Animals used in this experiment were of the second parity and crossbreds between Dutch Landrace and Norwegian Landrace. All 12 sows were of a commercial breed and at least half-sibs. After weaning their first litter three groups of animals were allotted on the basis of similarity of weaning date; estrus was synchronized for each group of 4 animals. All animals in one group were inseminated with semen of the same boar. All four animals of a group were also placed in calorimeters (van Es, 1966) on the same day about 110 of pregnancy.

Housing. Each sow was placed in a farrowing crate in the calorimeter on a rubber mat and remained in the crate from day 110 of pregnancy untill 28 days postpartum. They were allowed some movement once a week when they were weighed outside the calorimeter. Calorimeter conditions and management of sows were similar to those in the experiment of Verstegen et al. (1971). Faeces and urine of the sow were reasonably well separated through a gitter at the backside of the crate. Piglets were kept with the sow and housed in the calorimeter. Excretion of piglets was not added to that of the sow. Temperature was held constant at $19{ }^{\circ} \mathrm{C}$ postpartum. Relative humidity was maintained at 70 to $75 \%$. The piglets received extra heat by an infrared heating lamp. 
Feeding scheme for the sows. A commercial sow feed was used (lysine content $0.7 \%$ and metabolizable energy (ME) $12.2 \mathrm{MJ} / \mathrm{kg}$ ) during the first 110 days of pregnancy. During this period the sows were fed at maintenance plus additional feed for production of piglets and maternal tissue. Maintenance was assumed to be 420 $\mathrm{kJ}$ ME per unit of metabolic weight during the first month of pregnancy and $460 \mathrm{~kJ}$ ME during the second and third month of pregnancy. An additional feed for weight increase ( $300 \mathrm{~g} / \mathrm{d}$, i.e. about $3.7 \mathrm{MJ} \mathrm{ME})$ was given.

With this procedure the sows received $1.9(\mathrm{sd}=0.1) \mathrm{kg} / \mathrm{d}$ of the commercial feed up to day 110 of pregnancy. Starting with day 110 of pregnancy the composition of the diet was changed to the experimental formula as given in Table 1.

The daily quantity of feed was maintained during that period to provide $585 \mathrm{~kJ}$ of ME per $\mathrm{kg}$ metabolic weight per day for each sow. With this method $2.3 \mathrm{~kg}$ ( $\mathrm{sd}=$ $0.15 \mathrm{~kg}$ ) of feed were consumed daily by the animals during the last two weeks of pregnancy. This time was also used to give the sows an adaptation period to the experimental feed.

Sows farrowed in the calorimeters and the litters were standardized at 9 piglets in group 1, 8 in group 2 and 7 in group 3 . After parturition, two feeding levels were introduced: a low $(\mathrm{L})$ and a high $(\mathrm{H})$ level. The low level $(2.5 \mathrm{~kg}$ of feed per day, i.e. about $800 \mathrm{~kJ} \mathrm{ME} / \mathrm{kg}^{3 / 4}$ ) was based on maintenance and some feed for production. In this way the milk production was assumed to be mainly from sow's tissue. The high level ( 4.8 to $6 \mathrm{~kg} /$ day, i.e. about $1500 \mathrm{~kJ} \mathrm{ME} / \mathrm{kg}^{3 / 4}$ ) of feed was based on the assumption that the main part of milk would be produced from feed. This was obtained by supplying maintenance (assumed $420 \mathrm{~kJ} \mathrm{ME} / \mathrm{kg}^{3 / 4}$ ) and, in addition, feed for milk

Table 1. Composition of diet used for sows during lactation period and approximate analysis.

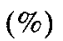

$\begin{array}{lc}\text { Maize (IFN 4-02-935) } & 25 \\ \text { Barley (IFN 4-00-549) } & 25 \\ \text { Lucerne (IFN 1-00-023) } & 10 \\ \text { Soya bean oil meal (IFN 5-04-604) } & 18 \\ \text { Wheat middlings (IFN 4-05-205) } & 16 \\ \text { Fish meal (IFN 5-13-459) } & 4 \\ \text { Limestone (IFN 6-02-632) } & 1 \\ \text { Calcium hydrogen phosphate (IFN 6-07-080) } & 0.5 \\ \text { Mineral vitamin premix for sows }{ }^{1} & 0.5 \\ & \\ \text { Composition by analysis } & \\ \text { Dry matter } & 87.47 \\ \text { Crude protein } & 21.38 \\ \text { Ether extract } & 3.29 \\ \text { Crude fibre } & 6.45 \\ \text { Ash } & 7.08\end{array}$

1 The premix contained: $\mathrm{Ca}, 23.5 \% ; \mathrm{P}, 10.8 \% ; \mathrm{Fe}, 1600 \mathrm{mg} / \mathrm{kg} ; \mathrm{Zn}, 8000 \mathrm{mg} / \mathrm{kg} ; \mathrm{Mn}, 4800 \mathrm{mg} / \mathrm{kg}$; $\mathrm{Co}, 50 \mathrm{mg} / \mathrm{kg} ; \mathrm{J}, 80 \mathrm{mg} / \mathrm{kg} ; \mathrm{Se}, 10 \mathrm{mg} / \mathrm{kg} ;$ vit. A, 1200000 I.U. $/ \mathrm{kg} ;$ vit. $D_{3}, 240,000$ I.U./kg; vit.B ${ }_{2}, 680$ $\mathrm{mg} / \mathrm{kg}$; niacin, $8600 \mathrm{mg} / \mathrm{kg}$; pantothenic acid, $1200 \mathrm{mg} / \mathrm{kg}$; cholin, $40000 \mathrm{mg} / \mathrm{kg} ;$ vit. $B_{12}, 3.2 \mathrm{mg} / \mathrm{kg}$; vit. $\mathrm{E}, 1200 \mathrm{I} . \mathrm{U} . / \mathrm{kg} ; \mathrm{dl}-\mathrm{methionin}, 60 \mathrm{~g} / \mathrm{kg}$. 
production assuming arbitrarely an efficiency of $60 \%$ for conversion of metabolizable energy from feed into milk energy (de Lange et al., 1980). Since animals will produce more milk at higher intake levels it was decided to aim at an intake of nearly ad libitum $(5 \mathrm{~kg}$ /day in the period from 7 to 14 days post partum and 5.5 to $6 \mathrm{~kg} /$ day in the period of 18 to 25 days post partum).

The crude protein level of the experimental feed was maintained over $20 \%$ in order to prevent a protein deficiency at a low feeding level.

Determination of milk production and components. Milk quantity and composition was determined with each sow on five days during lactation by weighing the piglets before and after suckling ( 6 times a day) according to the method described by Klaver et al. (1981). Corrections for losses due to metabolism and urine of piglets during suckling were made with methods of Klaver et al. (1981).

The figures for correction were derived from weighings in the present experiment. In the present study weight loss of piglets during suckling due to metabolism and urine secretion were estimated from determinations of loss of weight for periods of activity before suckling and loss of weight in piglets during admission to the sow without suckling. Mean losses during 212 of such periods were $0.61 \mathrm{~g}$ (sd = $0.52 \mathrm{~g}$ ) per piglet per minute. In 148 cases production of urine was observed. The mean weight loss when urine was produced was $35.1 \mathrm{~g}(\mathrm{sd}=38.4 \mathrm{~g})$ per piglet per observation.

The losses of weight during periods without urine production were calculated according to the following equation:

$$
y=0.180+0.337 X-0.04 Z
$$

in which: $y$, weight loss (g) per piglet per minute

$X$, metabolic weight per piglet $(\mathrm{kg})$

$Z$, age in days

Activity was expected to be higher if piglets are suckling and producing saliva. This type of extra activity was estimated during 21 periods with idle suckling. After correction for Eq. 1 an additional $0.68 \mathrm{~g}$ (sd $=0.44 \mathrm{~g}$ ) per piglet per minute weight loss was found. Correction for urine production took place with a regression equation in which independent variables were feeding level, age of the pigs, and liveweight of the pigs. In formula

$$
Y=-28.1+23.1 \mathrm{~F}_{\mathrm{i}}+28.9 X-5.2 Z \quad R^{2}=0.34
$$

in which: $Y$, weight loss $(\mathrm{g})$ per urination

$F_{i}$, feeding level $\left(F_{i}=0\right.$, high; $F_{i}=1$, low $)$

$X$, weight per piglet $(\mathrm{kg})$

$Z$, age in days

With Eq. 1 and Eq. 2 the corrections for weight losses in piglets during suckling were calculated. The corrected weight increase of the litter during suckling was considered as milk consumed from the sow by the piglets. 
A milk sample on the same day as the quantity of milk was sampled was obtained by hand milking of a different teat in each successive suckling and emptying the teat as good as possible. Milk samples from the successive sucklings were combined for that day and dry matter, $\mathrm{N}(\mathrm{Kjeldahl})$, ash (dry ashing at $550{ }^{\circ} \mathrm{C}$ ), ether extract and energy (bomb calorimetry) were determined. Lactose was obtained by subtracting fat, protein and ash from dry matter. Thus, on five different days with each sow, data of milk quantity and milk composition are known. The value of the method has been discussed by den Hartog et al. (1984). Milk production and weighings were not all made on the same day of the lactation period. Therefore corrections had to be made to make data of all sows comparable for the same day after parturition. The data on milk quantity, fat quantity and $\mathrm{N}$ quantity at various days were used in multiple regression analysis per sow with days as independent variable to estimate milk components at day 5, 10, 15, 20 and 25 for each sow. Only small corrections (intrapolations or extrapolations) to the same day were needed with this method. Percentages of fat in milk at day 5, 10,15, 20 and 25 were obtained by estimation of milk quantity and fat quantity at these days. With the same method all contents were calculated for these days.

Digestibility and energy balance trials. Energy balances were performed in two 7day periods post partum. Thus milk production and energy balances were done in the same part of lactation. Amounts of digestible energy (DE) and ME consumed by each sow were estimated in two 7-day balance trials. Because the animals remained continuously in the respiration chambers no extra adaptation time was required. (For measurement of digestibility, see Verstegen et al., 1985). For reason of measurements of heat production (indirectly from $\mathrm{CO}_{2}$ and $\mathrm{O}_{2}$ during day $2+3$ and day $5+6$ in each balance period) the young pigs received only the sow's milk and no additional creep feed was given.

Energy balance was calculated from data on heat production, corrected for that of the piglets in the litter, from energy in milk and from intake of metabolizable energy of sows (see Verstegen et al., 1985). The correction for metabolic rate of piglets has been done from measurement of heat production of sows and piglets together and estimated by multiple regression. Details are given by Verstegen et al. (1985). Metabolizable energy was obtained from digestible energy and from energy in urine.

Statistical analysis. Data on composition and quantities were first calculated for each sow for the same day post partum. Per sow with at least four measurements a regression line was calculated with minimally a second-degree orthogonal polynomial with lactation day as an independent variable. With the aid of these equations per sow milk quantity, fat quantity and $\mathrm{N}$ quantity were calculated on each of the following days of the lactation period: $5,10,15,20$ and 25 .

On day 5 the data were then analysed. The same was done with data on days 10 , 15,20 or 25 . 


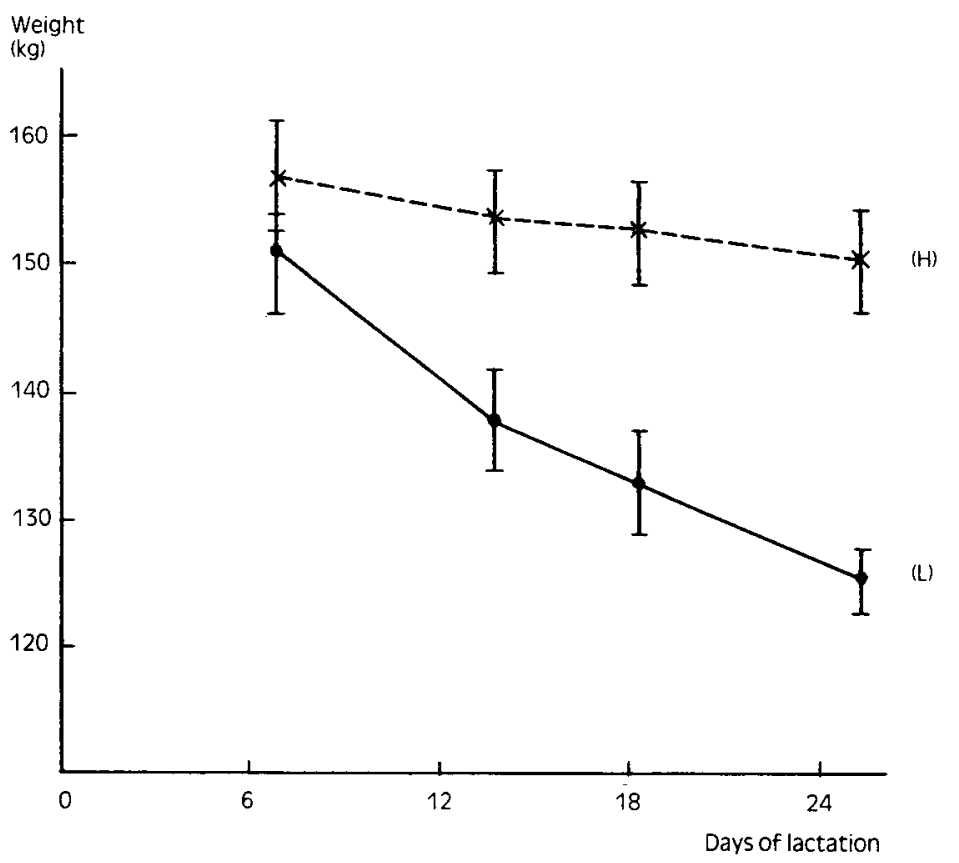

Fig. 1. Weight changes during lactation period of sows on a high $(\mathrm{H})$ or low $(\mathrm{L})$ feeding level.

\section{Results}

Performance. Weight change of sows, with regard to feeding level and lactation period, is given in Fig. 1. Sows fed on the low level of feeding lost much more weight during the first 25 days of lactation than did sows fed on a high level of feeding. On the high feeding level the weight loss from day 4 to 25 was about $10 \mathrm{~kg}$, whereas sows on the low level of feeding lost about $28 \mathrm{~kg}$ in this period.

Data on intake of energy and of $\mathrm{N}$ in the sows at the two feeding levels are given in Table 2. Sows on the high feeding level received more than twice the quantity of feed the animals at the low feeding level received. As a consequence intake of $\mathrm{ME}$ and $\mathrm{N}$ differed at a similar degree.

Table 2. Measured net daily intake of feed energy and nitrogen of lactating sows at the high and at the low feeding level and body weights of sows (SD within days).

\begin{tabular}{lcc}
\hline & High feeding level & Low feeding level \\
& & \\
Weight of sows $(\mathrm{kg})$ & $153.5(10)$ & $135.9(9)$ \\
Feed consumed $(\mathrm{kg})$ & $5.3(0.2)$ & $2.5(0.2)$ \\
Digestible energy $(\mathrm{MJ})$ & 69.3 & 33.9 \\
Metabolizable energy $(\mathrm{MJ})$ & 66.2 & 32.0 \\
$\mathrm{~N}(\mathrm{~g})$ & 182 & 86 \\
\hline
\end{tabular}


Table 3. Digestion coefficients (in \%) of gross energy, organic matter, $\mathrm{N}$, ether extract, crude fibre and nitrogen-free extract with sows on a high (H) or low (L) feeding level.

\begin{tabular}{llll}
\hline Feeding level & $\mathrm{H}$ & $\mathrm{L}$ & Difference H-L \\
& & & \\
Organic matter & 83.3 & 84.9 & $-1.6^{* *}$ \\
$\mathrm{~N}$ & 79.7 & 84.6 & $-4.9^{* * *}$ \\
Ether extract & 64.5 & 66.8 & -2.3 \\
Crude fibre & 50.5 & 54.9 & $-4.4^{*}$ \\
Nitrogen-free extract & 90.0 & 90.2 & -0.2 \\
Energy & 81.3 & 83.2 & $-1.9^{* *}$ \\
\hline
\end{tabular}

${ }^{*} \mathrm{P}<0.05 ;{ }^{* *} \mathrm{P}<0.01 ;{ }^{* * *} \mathrm{P}<0.005$.

Digestibility. The average digestion coefficients of the two 7-day periods on the high $(\mathrm{H})$ and on the (L) low feeding level are given in Table 3. Low levels of feeding resulted in somewhat higher coefficients of apparent digestibility. Between the two feeding levels differences in digestibility of organic matter, $N$ and crude fibre were significant $(P<0.05)$. Digestibility coefficients of ether extract and $\mathrm{N}$-free extract were higher at the low feeding level although not significantly higher. The higher coefficients of digestibility at the lower feeding levels were associated with an increased digestibility of gross energy. Digestible energy (DE) content for the feed was calculated from these data.

On the $\mathrm{H}$ feeding level feed contained $13.03 \mathrm{MJ} \mathrm{DE} / \mathrm{kg}$ and on the $\mathrm{L}$ feeding level 13.33 MJ DE/kg. Differences between the two estimations of DE are significant $(P<0.01)$. A similar calculation was made for $\mathrm{ME}$ content of feed. On the $\mathrm{H}$ feeding level 12.43 MJ ME/kg feed was found and on the $\mathrm{L}$ feeding level $12.58 \mathrm{MJ}$ $\mathrm{ME} / \mathrm{kg}$ of feed (difference not significant).

Milk production. Milk production of sows was significantly affected by feeding level and increased with the progress of lactation. In Table 4 data on daily gain of piglets and their milk intake are given. Data in Table 4 show that milk intake of piglets depends largely on the age of the piglets and feeding level of the sow. This effect is as-

Table 4. Effect of postpartum feeding level of sows on milk intake $\left(\mathrm{gd}^{-1}\right)$, energy intake ( $\mathrm{kJ}$ per pig per day) and ratios of milk to gain in piglets.

\begin{tabular}{|c|c|c|c|c|c|c|c|c|c|}
\hline \multirow[b]{2}{*}{ Feeding level $\rightarrow$} & \multicolumn{3}{|c|}{7 to 14 days } & \multicolumn{3}{|c|}{18 to 25 days } & \multicolumn{3}{|l|}{ Overall } \\
\hline & high & low & diff. & high & low & diff. & 7 to $14 \mathrm{~d}$ & 18 to $25 \mathrm{~d}$ & diff. \\
\hline Gain per piglet $\left(\mathrm{g} \mathrm{d}^{-1}\right)$ & 272 & 205 & $* *$ & 261 & 167 & ** & 246 & 218 & * \\
\hline Milk per piglet $\left(\mathrm{kJ} \mathrm{d}^{-1}\right)$ & 4944 & 4329 & ns & 5899 & 4762 & $* *$ & 4708 & 5382 & * \\
\hline Milk per gain & 3.74 & 4.09 & ns & 5.00 & 5.33 & ns & 3.84 & 5.15 & $* * *$ \\
\hline kJ milk per gain (g) & 18.22 & 21.26 & * & 22.84 & 29.13 & $* *$ & 19.36 & 25.70 & $* * *$ \\
\hline $\mathrm{kJ}$ gain $/ \mathrm{kJ}$ milk ${ }^{1}$ & 0.58 & 0.50 & * & 0.46 & 0.36 & $* *$ & 0.55 & 0.42 & $* * *$ \\
\hline
\end{tabular}

${ }^{*} \mathrm{P}<0.05 ;{ }^{* *} \mathrm{P}<0.01 ;{ }^{* * *} \mathrm{P}<0.001$.

1 Estimated from composition of piglets made by Berge and Indrebø (1954). 
sociated with a significant difference between treatments in amounts of milk consumed per piglet. Milk needed for gain of piglets (milk/gain) was clearly affected by age of piglets.

In Tables 5 and 6 the data on milk production and milk composition traits at various days after parturition are given. From Table 5 it is clear that milk quantity and fat content are not much influenced by stage of lactation. At the high feeding level milk quantity at day 5 differed from other days. Dry matter content in the milk did not differ between various stages.

Effects of feeding level on milk production, dry matter content and fat content are present from day 10 or 15 post partum onwards. Protein content in milk seems not to be affected by feeding level up to 25 days of lactation.

Effects of stage of lactation on total amount of energy, protein and fat excreted in milk are significant in sows within the high feeding level only (Table 6). Daily amounts of milk fat and milk protein excreted are not significantly affected by feeding level before day 20 post partum. However, energy content of the milk is similarly influenced by feeding level as is dry matter content and fat content in milk. Except for day 5, Table 6 shows an increasing difference between feeding levels in energy as milk consumed by the piglets, which is only significant at day 20 and 25 . Generally, the high feeding level results in higher quantities of milk and milk constituents produced by the sow (Table 6 ). However, milk composition is differently affected in such a way that a high feeding level results in lower concentration of dry matter, fat and protein.

Table 5. Milk production and milk composition estimated at various stages of lactation at the high $(\mathrm{H})$ and the low (L) feeding level.

\begin{tabular}{|c|c|c|c|c|c|}
\hline Stage of lactation ${ }^{1} \rightarrow$ & 5 days & 10 days & 15 days & 20 days & 25 days \\
\hline \multicolumn{5}{|l|}{ Milk production $(\mathrm{kg})$} & $9.94^{b}$ \\
\hline low $(L)$ & $6.59 \mathrm{ab}$ & $7.04^{\mathrm{ab}}$ & $7.33^{\mathrm{b}}$ & $6.86^{\mathrm{ab}}$ & $5.64^{\mathrm{a}}$ \\
\hline $\mathrm{H}-\mathrm{L}^{2}$ & -0.12 & 1.58 & $2.58^{*}$ & $3.50^{* * *}$ & $4.30^{* * *}$ \\
\hline \multicolumn{6}{|l|}{ Dry matter content (\%) } \\
\hline $\operatorname{high}(\mathrm{H})$ & 18.65 & 18.41 & 18.39 & 18.39 & 18.44 \\
\hline low (L) & 19.90 & 19.73 & 19.92 & 20.17 & 20.54 \\
\hline $\mathrm{H}-\mathrm{L}$ & -1.25 & $-1.32^{* * *}$ & $-1.53^{* * *}$ & $-1.78^{* * *}$ & $-2.10^{*}$ \\
\hline \multicolumn{6}{|l|}{ Fat content $(\%)$} \\
\hline $\operatorname{high}(\mathrm{H})$ & 6.98 & 6.89 & 6.79 & 6.63 & 6.38 \\
\hline low (L) & 7.80 & 7.92 & 8.10 & 8.19 & 8.18 \\
\hline $\mathrm{H}-\mathrm{L}$ & -0.82 & $-1.03^{* *}$ & $-1.31^{* *}$ & $-1.56^{* * *}$ & $-1.80^{*}$ \\
\hline \multicolumn{6}{|l|}{ Protein content $(\%)$} \\
\hline high $(\mathrm{H})$ & $5.75^{\mathrm{b}}$ & $5.11^{\mathrm{a}}$ & $4.97 \mathrm{a}$ & $5.07^{a}$ & $5.41^{\mathrm{ab}}$ \\
\hline low (L) & $6.05^{\mathrm{b}}$ & $5.53^{\mathrm{a}}$ & $5.47^{\mathrm{a}}$ & $5.63^{\mathrm{ab}}$ & $6.08^{\mathrm{b}}$ \\
\hline $\mathrm{H}-\mathrm{L}$ & -0.30 & $-0.24^{*}$ & $-0.50^{*}$ & $-0.56^{*}$ & $-0.67^{*}$ \\
\hline
\end{tabular}

${ }_{1}^{1}$ Data within the same line followed by different letters differ significantly $(\mathrm{P}<0.05)$.

Difference between feeding levels: ${ }^{*} \mathrm{P}<0.05 ;{ }^{* *} \mathrm{P}<0.01 ;{ }^{* * *} \mathrm{P}<0.001$. 
Table 6. Daily amount of milk constituents per sow ( $\mathrm{g}$ and $\mathrm{MJ}$ ) as affected by stage of lactation and feeding level.

\begin{tabular}{|c|c|c|c|c|c|}
\hline Stage of lactation ${ }^{1}$ & 5 days & 10 days & 15 days & 20 days & 25 days \\
\hline \multicolumn{6}{|c|}{ Fat production $\left(\mathrm{g} \mathrm{d}^{-1}\right)$} \\
\hline high $(\mathrm{H})$ & $447^{\mathrm{a}}$ & $594^{a, b}$ & $675^{\mathrm{b}}$ & $689^{b}$ & $637^{\mathrm{b}}$ \\
\hline low (L) & 512 & 557 & 592 & 560 & 460 \\
\hline $\mathrm{H}-\mathrm{L}^{2}$ & -65 & 37 & 83 & 129 & $177^{*}$ \\
\hline \multicolumn{6}{|c|}{ Protein production $\left(\mathrm{g} \mathrm{d}^{-1}\right)$} \\
\hline high (H) & $366^{\mathrm{a}}$ & $440^{a, b}$ & $493^{\mathrm{b}}$ & $526^{b}$ & $537^{\mathrm{b}}$ \\
\hline low $(\mathrm{L})$ & 392 & 390 & 401 & 386 & 345 \\
\hline $\mathrm{H}-\mathrm{L}$ & -26 & 50 & 92 & $140^{* *}$ & $192^{* * *}$ \\
\hline \multicolumn{6}{|c|}{ Energy content (MJ/kg milk) } \\
\hline $\operatorname{high}(\mathrm{H})$ & 4.96 & 4.81 & 4.74 & 4.66 & 4.56 \\
\hline low $(\mathrm{L})$ & 5.29 & 5.23 & 5.31 & 5.37 & 5.45 \\
\hline $\mathrm{H}-\mathrm{L}$ & -0.33 & $-0.42^{* *}$ & $-0.57^{* * *}$ & $-0.72^{* * *}$ & $-0.89^{*}$ \\
\hline \multicolumn{6}{|c|}{ Energy in milk ( $\left.\mathrm{MJ} \mathrm{d}^{-1}\right)$} \\
\hline high $(\mathrm{H})$ & $31.7^{\mathrm{a}}$ & $41.5^{\mathrm{b}}$ & $47.1^{\mathrm{b}}$ & $48.4^{\mathrm{b}}$ & $45.5^{\mathrm{b}}$ \\
\hline low (L) & 34.5 & 36.9 & 38.8 & 36.8 & 30.7 \\
\hline $\mathrm{H}-\mathrm{L}$ & -2.8 & 4.6 & 8.3 & $11.6^{* *}$ & $14.8^{* *}$ \\
\hline
\end{tabular}

${ }^{1}$ Data within the same line followed by different letters differ significant $(P<0.05)$.

${ }^{2}$ Differences between feeding level: ${ }^{*} \mathrm{P}<0.05$; $^{* *} \mathrm{P}<0.01$; $^{* * *} \mathrm{P}<0.001$.

\section{Discussion}

Milk production in sows is an important aspect in pig production. The piglets survival depends to a great deal on the milk supply (Moser \& Lewis, 1981). After 1 to 2 weeks of age addition of creep feed may help survival and the growth of piglets. Some years ago a lot of emphasis was put on composition of the sows diet during late gestation and lactation. Addition of fat to the diet was thought to improve the chances of survival of piglets. In general, an increase of fat content in colostrum and milk of sows, is expected when fat has been added to the diet during late pregnancy (Moser \& Lewis, 1981).

A low prepartum feeding level of sows was also found to increase fat content in milk during early lactation compared with a high feeding level (Klaver et al., 1981). Their finding suggests that a low level of feeding before and just after parturition would result in a similar effect as adding fat to the diet. The diet of sows before the birth of piglets may determine their development. It is also important to study the influence of feeding level after parturation on piglet's development. A recent study of Lellis \& Speer (1983) indicates that source of energy in lactation diet of sows may influence development of piglets and weight loss of sows. The present experiment was designed to give information of the effect of level of intake ( $H$ and $L$ ) on amounts of milk and composition of milk produced by the sows. In the low level group (L) most of the milk needed to be produced from the sow tissues and in the 
other group $(\mathrm{H})$ nearly all milk could be produced from feed, especially in the period of day 15 to day 25 postpartum.

Sow's bodyweight. Effect of feeding level during lactation on performance of sows is most clearly demonstrated by the weight loss of sows during the first 25 days after farrowing. During day 7 to 14 post partum sows at the $\mathrm{H}$ feeding level lost $3.3 \mathrm{~kg}$ and those on the $\mathrm{L}$ level lost $13.0 \mathrm{~kg}$ live weight. During day 18 to 24 these losses were 1.3 and $8.5 \mathrm{~kg}$, respectively, at the $\mathrm{H}$ and $\mathrm{L}$ feeding levels.

Apparently a high feeding level (nearly ad libitum) can prevent weight loss of sows more in week 3 to 4 than at the beginning of lactation. This may be associated with the limited feed intake in the first days after parturition (de Lange et al., 1980). The effects of feeding level on weight loss have been demonstrated also in experiments of Smith (1959b) and O'Grady et al. (1975). They also claim that feeding level during pregnancy has an effect on weight loss during lactation regardless of feeding level post partum. In the present experiment both groups were fed similarly during pregnancy and were in good condition at farrowing (Geerse \& Mesu, 1981).

The question remains: what is most beneficial to the piglets? It may be argued that a good development of piglets will be beneficial for piglet survival. Data from this experiment demonstrated that a better development of piglets judged by weight gain occurs at least from day 7 onwards. A high feeding level will be benefical from that time onwards at least. However, this does not guarantee a reduction in mortality during the first week of life because feeding level will not influence milk quality and milk composition very much in the first days post partum (de Lange et al., 1980).

Bodyweight gain of suckling piglets will be improved by an increased milk energy. This may be a similar effect as reported by Moser \& Lewis (1981). They noted from literature an increase in milk yield with addition of fat to the diet. Lellis \& Speer (1983) found an increased fat percentage in milk, when a diet with more fat was given to sows. From the present study, however, a lower percentage of fat in milk was found in sows receiving a higher feeding level. Despite this especially in late lactation (day 15 and later) a higher total fat output in milk from sow at a high feeding level can be expected. Apparently it is important to assess feeding level and fat in the diet separately. Piglets clearly develop better when the sow, at which they nurse, receives more feed.

Conversion rate of milk energy into the piglets body energy was about 36 to $58 \%$ (Table 4). The range of these data is similar to that determined by Lodge (1957) and by Smith $(1959,1960)$. The conversion will depend very much on the level of milk production, i.e. level above maintenance intake of piglets. Digestibility of sows' feed was reduced somewhat at the higher feeding level. The reason for this difference may be associated with the rate of passage (NRC, 1980). Feeding level of sows had no significant effect on metabolizability of the feed in this experiment. At the higher feeding level less energy was found in urine associated with a smaller amount of $\mathrm{N}$ in urine. Similarly the metabolizability was not affected by stage of lac- 
tation. This agrees with results of experiments by Gütte \& Lenkeit (1960), Aherne \& Speer (1974) and de Lange et al. (1980). Feeding 2.5 to $3 \mathrm{~kg}$ of feed more per day (Table 2 ) resulted in about $2 \mathrm{~kg}$ more milk produced per day (Table 5) and about 1 $\mathrm{kg}$ less body weight loss per day in the sow (Fig. 1). Therefore, some 75 extra $\mathrm{kg}$ of feed during 4 weeks of lactation is equivalent to about 50 to $60 \mathrm{~kg}$ of milk and in addition to that 25 to $30 \mathrm{~kg}$ of body tissues in sows. It can be calculated that $75 \mathrm{~kg}$ of feed included about $940 \mathrm{MJ}$ of metabolizable energy or about $600 \mathrm{MJ}$ of net energy (average efficiency $65 \%$ ). Therefore about $40 \mathrm{~kg}$ of milk need not to be produced from body tissue. This agrees well with $\mathrm{N}$ balances of the sow. (Verstegen et al., 1985).

As a consequence of an increased milk output piglets with these high-level sows gained about 30 to $40 \%$ more weight (Table 4 ) in 25 days of lactation.

Milk composition. A high feeding level in sows resulted in a high milk production rate with a low fat content. As a consequence dry matter content in milk is somewhat reduced. After two weeks of lactation at a low feeding level less milk is produced with a higher dry matter and especially a higher fat and energy content. The available energy from milk per suckling pig was reduced in those sows compared to the sows at the high feeding level. The reduction in individual energy consumption of piglets is somewhat less than expected from reduction in milk production because of the higher fat content of milk in the sows of the low feeding level. Because the concentration of lactose (calculated by difference) and protein in milk are not affected clearly by feeding level, sows with a higher feeding level produce more energy per piglet as solids-non-fat.

One aspect of feeding level in lactating sows is protein supply. It was assumed that a high protein content in the diet $(>20 \%)$ would limit the use of protein for milk from body protein. In the present experiments sows at the low level $(2.5 \mathrm{~kg}$ of feed with $21.3 \%$ crude protein) received about $525 \mathrm{~g}$ of crude protein. This is less than the amount advised in the Netherlands for lactating sows. However it was thought that energy would be drawn much more from body reserves than protein. Moreover $\mathrm{N}$-balances at the high level were found to be around equilibrium. Therefore sows received sufficient protein for milk production (Verstegen et al., 1985). However, if milk production and $\mathrm{N}$ balances are resp. under and overestimated protein in feed may be deficient. Since $\mathrm{N}$ balances were already negative in sows on the low feeding level lower milk yield may be associated with protein as well as energy status in the sow.

\section{References}

Aherne, F. X. \& V. C. Speer, 1974. Energy and nitrogen metabolism and performance of responses of lactating sows fed thyro protein. Journal of Animal Science 38: 310-318.

Berge, S. \& T. Indreb $ø, 1954$. Composition of body and weight gain of suckling pigs. Meldinger Norges Landbrukhøgskole 33: 481-500.

Bowland, J. P., 1967. Energetic efficiency of the sow. Journal of Animal Science 26: 533-540.

DeB. Hovell, F. D., J. G. Gordon \& R. M. Mac Pherson, 1977. Thin sows. 2. Observations on the energy and nitrogen exchanges of thin and normal sows in environmental temperatures of $20^{\circ} \mathrm{C}$ and $5{ }^{\circ} \mathrm{C}$. Journal of Agricultural Science 89: 523-533. 


\section{G. J. M. VAN KEMPEN, C. GEERSE, M. W. A. VERSTEGEN AND J. MESU}

Es, A. J. H. van, 1966. Labour-saving methods for energy balance experiments with cattle; Description of equipment and methods used. Netherlands Journal of Agricultural Science 14: 32-46.

Geerse, C. \& J. J. Mesu, 1981. De energetische efficiëntie van melkvorming bij zeugen. Student thesis, Dept. of Animal Nutrition and Dept. of Animal Physiology, Agricultural University, Wageningen.

Gütte, J. O. \& W. Lenkeit, 1960. Langfristige Untersuchungen zum äuszeren und inneren Stoffwechsel des graviden und laktierenden Schweines. 9. Mitteilung: Energieumsatz und Nährstoffbedarf saugender Sauen. Zeitschrift für Tierphysiologie, Tierernährung und Futtermittelkunde 15: 164-191.

Hartog, L. A. den, M. W. A. Verstegen, M. A. T. M. Hermans, G. J. Noordewier \& G. J. M. van Kempen, 1984. Effect of weight loss in piglets during suckling on estimation of milk production. Zeitschrift für Tierphysiologie, Tierernährung und Futtermittelkunde 51: 148-157.

Klaver, J., G. J. M. van Kempen, P. G. B. De Lange, M. W. A. Verstegen \& H. Boer, 1981. Milk composition and daily yield of different milk components as affected by sow condition and lactation/feeding regimen. Journal of Animal Science 52: 1091-1097.

Lange, P. G. B. de, G. J. M. van Kempen, J. Klaver \& M. W. A. Verstegen, 1980. Effect of condition of sows on energy balances during $7 \mathrm{~d}$ before and $7 \mathrm{~d}$ after parturition. Journal of Animal Science 50: 886892.

Lellis, W. A. \& V. C. Speer, 1983. Nutrient balance of lactating sows fed supplemental tallow. Journal of Animal Science 56: 1334-1339.

Lodge, G. A., 1959. The energy requirements of lactating sows and the influence of level of food intake upon milk production and reproductive performance. Journal of Agricultural Science 53:177-191.

Moser, B. D. \& A. J. Lewis, 1981. Fat addition to sow diets. A review. Pig News and Information 2 (3): 265-269.

O'Grady, J. F., F. W. H. Elsley, R. M. Mc Pherson \& J. Mc Donald, 1975. The response of lactating sows and their litters to different dietary allowances, 2 weight changes and carcass composition of sows. Animal Production 20:257-265.

Smith, D. M., 1959a. The yield and composition of milk from sows fed varying proportions of separated milk and concentrates. New Zealand Journal of Agricultural Research 2: 1057-1070.

Smith, D. M., 1959b. The yield and composition of milk from sows fed on three ration levels. New Zealand Journal of Agricultural Research 2: 1071-1083.

Smith, D. M., 1960. The yield and energy content of milk and the energetic efficiency of sows on different levels of nutrition during gestation and lactation. New Zealand Journal of Agricultural Research 3: 745-763.

Verstegen, M. W. A., A. J. H. an Es \& H. J. Nijkamp, 1971. Some aspects of energy metabolism of the sow during pregnancy. Animal production 13: 677-683.

Verstegen, M. W. A., J. Mesu, G. J. M. van Kempen \& C. Geerse, 1985. Energy balances of lactating sows in relation to feeding level and stage of lactation. Journal of Animal Science (in press). 